\title{
Replacement of Municipal Political Elite as a Tool for Seizing Power and Consolidating an Authoritarian Regime in Slovakia 1938-1940"
}

Martin Pekár

vol. 9, 2020, 1, pp. 93-111

DOI: https://doi.org/10.33542/CAH2020-1-04

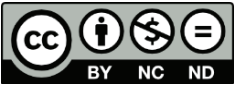

The main aim of this article is to present a comparative historical analysis of the mechanisms for the replacement of the political elites after the collapse of interwar Czechoslovakia and the declaration of the Slovak State under the influence of Nazi Germany in the years 1938-1940 at the level of municipal self-government with regard to the onset of an authoritarian regime. The subjects of the research are two towns, Prešov and Nitra, which provide an opportunity to look for similarities and differences in the changes implemented in two socio-economically and demographically similar towns with different political climates. The research is based on primary and secondary historical sources confronted mainly with the theories of V. Pareto, R. Michels and J. J. Linz. Historical developments in Slovakia in the years 1938-1940 and the process of the replacement of municipal elites correlates with the framework formulated in the sociological theories of Pareto and Michels. The process of the replacement of municipal elites contributed also to the gaining of characteristic elements of the authoritarian regime in the sense of the definition of J. J. Linz established in Slovakia by the Hlinka Slovak People's Party.

Keywords: Municipal Political Elite. Authoritarian Regime. Slovakia. 1938-1940. Prešov. Nitra.

\section{Introduction}

One of the consequences of growing internal political tensions in Czechoslovakia during the Munich crisis of autumn 1938 was the replacement of political elites and the associated rise of a non-democratic, authoritarian regime, inspired by Italian fascism and led by the Hlinka Slovak People's Party (Hlinkova slovenská l'udová strana, hereinafter the HSL'S) in the Slovak part of the common state. The crisis and the subsequent avalanche of events included extensive replacements of political elites at lower levels of governance, including of individual towns and villages. A knowledge of the nature of the incoming political elite - that part of the society which possessed power and was to determine the direction of further development and an understanding of the mechanisms for the seizure of power at all levels of socio-political life are prerequisites for the understanding both of society at that time and of the everyday political practices, that is, the essence of the HSL'S regime itself. ${ }^{1}$ Without knowing about the new elites and understanding the process of their formation, it is impossible to understand the overall scope of the application of non-democratic

\footnotetext{
This article is published as an outcome of the project supported by Scientific Grant Agency of the Ministry of Education, science, research and sport of the Slovak Republic and the Slovak Academy of Sciences under no 1/0254/17 Strategies of Surviving the Holocaust and Municipal Elites. A substantial part of the article which examines Prešov was published as a case study in Slovak under the title Výmeny mestských politických elít na Slovensku po páde medzivojnovej československej demokracie (Prešov, 1938-1944) (Studia historica Nitriensia, 2019, vol. 23, no. 1, pp. 144-157). The author of taken parts of the text is M. Pekár.

1 For more details on the HSL'S and its regime in 1938-1940, see: LORMAN, The Making of the Slovak People's Party. BYSTRICKÝ, Slovakia from the Munich Conference, 157-174. TOKÁROVÁ, Slovenský štát. BAKA, Politický systém.
} 
principles, which, among other factors, was based on the (seeming) legitimacy of the new political elites, their performance, abilities, values and, in particular, the degree of cooperation of their members at all levels of the bureaucratic machinery. While the seizing of power by the Hlinka Slovak People's Party considered at the state-wide level is a relatively well-researched area, ${ }^{2}$ attention has not been paid in such detail either to the way in which the seizure of power and personnel replacements took place at the local level or to the resulting socio-political consequences. ${ }^{3}$

1 Theoretical background (municipal elite and state regime) and research goals

In general, there is little consensus on the definition of the term elite in sociological (and historical) research. ${ }^{4}$ In our article the definition of the term elite and its analysis are based on four general principles (shared by all three prominent elitists - Gaetano Mosca, Vilfredo Pareto and Robert Michels) summarized by Robert D. Putnam: 1) political power is distributed unequally; 2) essentially, people fall into only two groups: those who have "significant" political power and those who have none; 3) the elite is internally homogeneous, unified and self-conscious; 4) the elite is largely self-perpetuating and is drawn from a very exclusive segment of society. ${ }^{5}$ Therefore, we are confining it exclusively to the area of politics and the area of power understood in terms of Max Weber's definition as an ability to assert one's will in social relations. By the narrower term municipal political elite, we understand a relatively small cohesive social group whose members share common values and interests. In their hands is concentrated political authority allowing them to influence the direction of local socio-political developments in accordance with their own interests. The members of the municipal political elite hold the highest positions in the municipal self-government. They have executive or regulatory competences within their political area, so they are actively involved in (or they are at least very close to) political decision-making on serious issues relating to society's development (not only political, but also economic, cultural etc.). They monopolize their position. In contrast to this municipal political elite, there is a numerous mass of politically passive (inactive) people - residents who are more or less eliminated from the decision-making process, it being directed and controlled by the elite. ${ }^{6}$

Elite replacements in correlation with changes in state regimes were examined by Vilfredo Pareto, author of the theory and model of elite circulation. ${ }^{7}$ Circulation amongst the members of the elite and non-elite (within or amongst classes) is a typical characteristic of the elite. Political, economic and ideological factors are responsible for continuing this process. Pareto distinguishes between large and small elite exchange cycles. The large cycle is associated with massive violent revolutionary changes; the small cycle is linked in particular to the processes of the replacement acting between

2 Most recently in Slovak historiography e.g.: FERENČUHOVÁ - ZEMKO, V medzivojnovom Československu. HRADSKÁ - KAMENEC, Slovenská republika. In addition: HOENSCH, Die Slowakei und Hitlers Ostpolitik. TÖNSMEYER, Kollaboration als handlungsleitendes Motiv?, 25-54.

3 For more details, see: BYSTRICKÝ, Politické rozvrstvenie spoločnosti, 120-137. NIŽŇANSKÝ, Zmocnenie sa vlády, 14-44. PEKÁR, Zlomové udalosti, 120-131.

4 WASNER, Eliten in Europa, 16.

5 PUTNAM, The Comparative Study, 3-4.

6 For more details, see: MOSCA, The Ruling Class. WEBER, Wirtschaft und Gesellschaft.

7 PARETO, The Circulation of Elites, 551-558. 
members of the ruling elite and members of various social groups outside the ruling elite. Whether particular elites stay in power or not, whether they are partially or fully replaced or not, the fact remains that they remain in vital positions. Natural small-cycle replacement processes, which according to Pareto are necessary, usually take the form of the co-opting of individuals with the desired characteristics or of individuals infiltration with the support of social groups that do not participate in the government. ${ }^{8}$ According to Robert Michels, Pareto's theory must be accepted with reserve because in most cases there is not a simple replacement but a process of intermixture. ${ }^{9}$

The possibilities for joining the power elite are not open to all people in a nondemocratic regime, but they are based on strictly defined conditions (ideological focus, membership in the ruling party, nationality, religion etc.). Generally, the elite in authoritarianism, according to Juan J. Linz, is characterized by a certain heterogeneity in its background, a smaller number of professional politicians (persons who have built their careers in purely political organizations) and conversely a large number of politicians from bureaucratic, military or religious circles or other interest groups. ${ }^{10}$

Based on this theoretical framework, the main aim of this article is a comparative historical analysis of the replacement mechanism of the political elites after the declaration of Slovak autonomy on 6 October 1938 and subsequently after the declaration of independence of the Slovak State on 14 March 1939 at the level of municipal self-government. The subject of the analysis and the comparison are two towns - Prešov and Nitra - and their selected self-government bodies as defined by then valid legislation ${ }^{11}$ - mayor, municipal assembly and municipal council in the period before 1938 or government commissioner and advisory committee after 1938 . Following above mentioned sociological characteristics, the primary historical research on this example of two selected towns can illustrate a number of accompanying features peculiar to the process of the circulation, the replacement of municipal political elites and the seizure of political power in a non-democratic regime on the local level -such as power interventions by central authorities, the replacement of elected bodies by appointed ones, changes in the competences of self-government, differences in the social profile of the new municipal political elite's members etc. - and will bring new knowledge about the state regime in Slovakia in the period 1938-1945 and the role of municipal elites in the process of transition from democracy to authoritarianism. Prešov and Nitra provide the opportunity to look for similarities and differences in the changes implemented in these two socio-economically and demographically similar towns with different political climates. In addition to the comparison between the replacement processes of the elites ${ }^{12}$ and the mechanisms of the seizure of political power in the two selected towns, attention is also paid to the question of continuity within those elites.

\footnotetext{
8 WASNER, Eliten in Europa, 47-50. KELLER, Dějiny klasické sociológie, 309-310.

9 MICHELS, Political Parties, 378.

10 LINZ, Totalitarian and Authoritarian Regimes, 161.

11 Acts no. 75 and 76/1919.
}

12 Analogically, it would be interesting and important to analyse similar processes within that part of the that part of the civil service which is on the local level very close to the municipal political elite. However, this analysis is not our goal. Generally, it applies to the non-democratic regime in Slovakia 1938-1945 that municipal servants were replaced for political and racial reasons. 
From the point of view of the theory of authoritarianism we want to demonstrate that the process of the municipal elite's replacement significantly contributed in the case of Slovakia in the years 1938-1940 to the shaping of the characteristics of the authoritarian regime. This is to say that the process of municipal elites' replacement can be also interpreted both as a tool for the seizure of power and as a tool for the establishing of an authoritarian regime, defined again by Linz in comparison to a totalitarian regime. According to him, the authoritarian regime only partially fulfils three key characteristics of the totalitarian regime-monistic centre of power, elaborated ideology and citizen mobilization ${ }^{13}$ - due to administrative inefficiency, economic underdevelopment or external influences. ${ }^{14}$ That this Linz definition applies to Slovakia 1938-1945 was convincingly proved by Z. Tokárová, who, however, did not deal with the process of municipal elites' replacement in her analysis. ${ }^{15}$

\section{Subjects of the analysis and comparison (towns of Prešov and Nitra)}

The town of Prešov entered the Munich crisis as a local centre of the economically poorly developed north-eastern Slovakia, which was in the shadow of the traditional regional metropolis - the city of Košice. However, after the occupation of Košice by Hungary as a result of the First Vienna Award, Prešov became the second most important town of Slovakia after Bratislava in terms of its strategic importance, which was reflected in the increase in the population (especially of soldiers and refugees). The increase in the importance of the town was naturally reflected in the rising interest in the gaining of control of the town leadership by the incoming political group represented by the HSL'S, which had had no significant influence here in the interwar period.

In the interwar period, the town of Nitra suffered similar economic problems as Prešov - poor transport connections and a lack of capital. However, Nitra was located in a fertile area and therefore it was the regional centre of the food industry. In terms of population growth, this town stagnated. Nitra was one of the traditional historical and religious centres, ${ }^{16}$ with a fixed position in the Slovak national history, and in the 1930s national mobilization took place directly in its area, so the position of the HSLS in Nitra's municipal government was stable, but until the establishment of the Slovak State was not clearly dominant.

Both towns had a varied nationality structure with a large Jewish community in the interwar period. This situation changed in the period under review in connection with the development of international relations and anti-Jewish policy. ${ }^{17}$

13 LINZ, Totalitarian and Authoritarian Regimes, 70.

14 LINZ, An Authoritarian Regime, 293.

15 TOKÁROVÁ, Slovenský štát.

16 Bishopric was established in Nitra already in 880. The bishop of Nitra between 1920 and 1948, Karol Kmet'ko, was actively involved in the process of establishing Czechoslovakia in 1918, and in 1920 he was elected as Deputy of the National Assembly for the HSLS. However, he resigned shortly after his accession to the episcopal seat.

17 For more details on the history of Prešov and Nitra in the years 1938-1945 see: PEKÁR, Prešov 1938-1945, XVII-LIV. PALÁRIK - MIKULÁŠOVÁ - HETÉNYI - ARPÁŠ, The City and Region. FUSEK - ZEMENE, Dejiny Nitry. 
Table 1: Residents of Prešov and Nitra ${ }^{18}$

\begin{tabular}{|l|c|c|c|}
\hline & 1930 & 1938 & 1940 \\
\hline PREŠOV19 & 21775 & 21016 & 24394 \\
\hline Slovak & - & 15558 & 17479 \\
\hline Hungarian & 937 & 745 & 626 \\
\hline German & 947 & 253 & 487 \\
\hline Jewish & $\begin{array}{c}3965 \text { (by } \\
\text { religion) }\end{array}$ & $\begin{array}{c}\text { 3892 (by } \\
\text { religion) }\end{array}$ & $\begin{array}{c}4381 \text { (by } \\
\text { nationality) }\end{array}$ \\
\hline
\end{tabular}

\begin{tabular}{|l|c|c|c|}
\hline & 1930 & 1938 & 1940 \\
\hline NITRA $^{20}$ & 21283 & 21323 & 22552 \\
\hline Slovak & - & 18835 & 16034 \\
\hline Hungarian & 961 & 776 & 1319 \\
\hline German & 558 & 197 & 467 \\
\hline Jewish & $\begin{array}{l}\text { 3809 (by } \\
\text { religion) }\end{array}$ & $\begin{array}{c}3976 \text { (by } \\
\text { religion) }\end{array}$ & $\begin{array}{c}4320(\text { by } \\
\text { nationality) }\end{array}$ \\
\hline
\end{tabular}

3 The process of the abolition of self-government (Slovakia, October 1938-1940)

On 6 October 1938, Slovak autonomy was unilaterally declared in the town of Žilina by representatives of the HSLS. The occupation of the highest power positions by members of the Hlinka Slovak People's Party and the ban or the forced unification with the HSL'S of other political parties was immediate after 6 October 1938, and was accompanied by the adoption of several measures to take power at the regional and local political levels, although this was not supported by either the Žilina Agreement ${ }^{21}$ or any other political document. This was a unilateral activity of the HSLS and its supporters. The measures were based on an extreme interpretation of the Czechoslovak legal rules in force and led to the removal of political opposition representatives from municipal government authorities or to the complete abolition of democratically elected municipal governments. ${ }^{22}$

The process of the abolition of elected municipal government in Slovakia through the analysis of legislative measures has been studied in detail by O. Podolec, who divided the process into four phases. The first three phases fall within the period by the end of 1938, the fourth phase took place at the turn of 1943/1944 during the existence of the Slovak State. ${ }^{23}$

According to $\mathrm{O}$. Podolec, interventions into municipal self-government began immediately after the declaration of autonomy on 6 October 1938. Instantly, there were created power centres of the HSL'S - regional or local national committees, more or less spontaneously formed, which usurped the competencies of self-governing

18 In 1930, the census stated Czechoslovak nationality, so it is not possible to state the number of Slovaks (a significant number of Czechs who lived in Slovakia left from the autumn of 1938, voluntarily or forced, for the Czech part of the country). The Jewish population maintained one religious identity, but changed their national identity situationally. Therefore, in the table we present data for the years 1930 and 1938 according to Jewish religion in addition to declared nationalities, allowing that the 1938 populations by category thus sum to more than the total town populations. By 1940, Jews were already legally obliged to declare their Jewish nationality in accordance with their religion. The difference in 1940 between the stated total populations and the sums of the four mentioned nationalities is formed by members of other national minorities.

19 Data source: PEKÁR, Prešov 1938-1945, XXII-XXV.

20 Data sources: Štátny archív v Nitre [State archives in Nitra] (hereinafter ŠA Nitra), Pamätná kniha mesta Nitry II, fol. 91. ŠA Nitra, Nitrianska župa III, box 119, no. 5914/1940-adm.

21 The Žilina Agreement was signed on 6 October 1938 by representatives of political parties who were invited by the HSL'S leadership to support their effort to gain the autonomy of Slovakia in Czechoslovakia. In practice, the agreement meant the forced unification of other political parties with the HSL'S.

22 In detail: NIŽŇANSKÝ, Zmocnenie sa vlády, 14-44.

23 PODOLEC, Postavenie obecnej samosprávy, 647-668. 
bodies. The official instructions of the autonomous government of 12 October de facto legalized the existence of national committees and recommended that the authorities respect and pragmatically exploit the authority of these national committees. Slovak autonomous government ranged between the national committees and selfgovernment bodies, while respecting the existence of elected municipal government and communicating with it; this meant the application of procedures within the limits of the legislation in force. In the next step, power interventions into the municipal assemblies were carried out in those towns or municipal assemblies in which the incoming political representation did not dominate or in which the mayor was politically "unsatisfactory". In these cases, the elected municipal government was completely dissolved, and the government commissioner of the town was appointed (pursuant to $\S 28$ of Act No. 243/1922). As mentioned, the incoming HSL'S regime used extreme legal measures in the form of temporary measures in the administration of municipal affairs to abolish self-government and seize power. The third phase of the interventions is associated with the consolidation of the new situation and the dissolution of national committees. The last phase, which is not the object of our attention in this article, ${ }^{24}$ was supposed to definitively remove the remains of interwar self-government. As part of the practical implementation of the newly adopted Act No. 171/1943 on changes in the self-government of municipalities, which came into force on 1 January 1944, party elections to municipal committees were held. ${ }^{25}$

\section{1 "Machtergreifung" in autumn 1938}

\subsubsection{Prešov}

As already mentioned, Prešov was not a town with a strong HSL'S position. ${ }^{26}$ The replacement of the political elite and the seizure of political power in 1938 took place dramatically and precisely according to the phases described by 0 . Podolec.

Immediately before the start of the autumn crisis, the town leadership was still in the hands of the political representation democratically elected in the municipal elections in $1932,{ }^{27}$ because the municipal elections planned in Prešov for the autumn of 1938 were not held due to the developments after Munich. After the municipal elections in 1932, advocate Alexander Duchoň became the mayor of Prešov. He was a candidate for the Czechoslovak National Democracy, for which he had been an elected member of the Slovak Land Assembly ${ }^{28}$ since 1929 . His position was not based on party affiliation, but on the fact that he was a famous person who had been active in regional politics and the public life of the town since 1913. The municipal assembly of Prešov had

24 The comparison is impossible due to lack of primary sources in the case of Nitra. For details about the fourth phase in Prešov, see: PEKÁR - TOKÁROVÁ, Výmeny mestských politických elít, 153-154; or PEKÁR. Zmeny v samospráve, 83-90. http://dejiny.unipo.sk/PDF/Dejiny_1_2008.pdf.

25 PODOLEC, Postavenie obecnej samosprávy, 647-668.

26 For example in the municipal election of 1927, the HSL'S party in Prešov received only $7.2 \%$ and in 1932 $18.6 \%$ of the votes. This was significantly less than in the elections to the Chamber of Deputies of the National Assembly, in which the HSL'S received $28.27 \%$ in 1929 and $30.12 \%$ in 1935. (These results are in Slovakia, not nationwide. In 1935, the HSL'S went into an election in coalition with three other peripheral political parties.) On the situation in Prešov in more detail, see: SZEGHY-GAYER, „Vrát'me si mesto!", 56-68. PEKÁR - TOKÁROVÁ, Výmeny mestských politických elít, 144-157.

27 The municipal elections did not take place on one date. They were held in the second half of 1931 (e.g. Nitra) and early 1932 (e.g. Prešov)

28 Slovak Land Assembly - a body of state government territorially identical with Slovakia which was created together with Slovak Land Office in 1928. 
42 members, ${ }^{29}$ whose mandates were divided among 14 political parties or election groupings. The two strongest political parties - the Land Christian Socialist Party (party of the Hungarian minority) and the left-wing Communist Party of Slovakia - had eight seats; the other parties had one to three seats. The HSL'S had three deputies - Vojtech Raslavský (he was also deputy mayor and a member of the municipal council), Vincent Šoltys and Štefan Haluška. ${ }^{30}$

On 6 October 1938, Slovak autonomy was declared in the town of Žilina. Already on 7 October, the local organization of the HSL'S created the local Slovak National Committee in Prešov. Its founding was initiated by Gejza Fritz, active in national politics for many years - a parliamentarian since 1925, a senator since 1935, in 1938 elected to the autonomous Slovak parliament and after 14 March 1939 the minister of justice. ${ }^{31}$ In the town he was an extended arm of the HSLS leadership. Fritz soon assumed the position of chairman of the Slovak National Committee of Prešov after "hesitant" Vojtech Raslavský, the chairman of the local party organization. The Slovak National Committee competed with elected bodies and organized rallies, mostly attended by high school youth, which applied pressure for political changes in line with the events of 6 October. In the municipal government, these changes were reflected first in the withdrawal of the mandate of the Communist Party deputies and the appointment of alternates. Mandates in the municipal assembly were received by four other HSL'S supporters - Florian Staš, Ján Meličko, Alojz Válik and Alexander Chrappa (all members of the Slovak National Committee). However, the functioning of the modified assembly was episodic. The assembly met at a single formal sitting during which the honorary citizenship of the town was granted to the prime minister of the autonomous government Jozef Tiso.

Even these changes failed to ensure that the HSL'S prevailed, and therefore on 24 October 1938, the Slovak Land Office in Bratislava dissolved the self-government bodies in Prešov and on 27 October 1938 appointed the government commissioner of the town, who subsequently appointed his advisory committee. ${ }^{32}$ Alexander Chrappa (director of the grammar school) was appointed as the government commissioner, who took over the position from the aforementioned Alexander Duchoň. The members of his advisory committee were: Andrej Germuška (director of the teaching institute), Florián Staš (district secretary of the HSL'S), Ján Meličko (bank clerk), Alojz Válik (bank clerk), Jozef Makara (teacher), Ján Onofrej (farmer), Titus Ripka (bank clerk) and František Pjontek. ${ }^{33}$ All of them belonged to the middle class and were nationally oriented Catholics, but above all, all of them except Pjontek were members of the Slovak National Committee of Prešov.

Looking at the new "revolutionary" town leadership, we observe that continuity with the elected assembly of 1932 was represented by only one member - Jozef Makara, who, however, was not elected to the municipal assembly for the HSL'S in 1932, but

29 The number of deputies was determined by $\S 9$ of Act no. 75/1919. The 16-member municipal council was elected from among the elected deputies. There was a chief municipal notary, who was appointed by the Ministry of the Interior and who represented the state in the town leadership.

30 Štátny archív v Prešove [State archives in Prešov] (hereinafter ŠA PO), Okresný úrad Prešov 1923-1945, box 127. Also, in detail: Pamätná kniha mesta Prešova, 2.

31 For more details, see: PEKÁR, Dr. Gejza Fritz, 394-404.

32 PEKÁR, Prešov 1938-1945, XVIII-XX.

33 LUPTÁK, Šariš v budovaní slovenskej štátnosti, 2. 
for the Catholic Association. He continued in the administration of the town after 14 March 1939. ${ }^{34}$ The members of the HSL'S, who had had a peripheral position in the previous period because the party did not have a significant background in the Prešov electorate, came into the town leadership. By the intervention of the new Slovak autonomous government, the two most powerful democratically elected parties in 1932 were eliminated. They were not only political opponents but also ideological enemies of the HSL'S (Hungarians and communists). At that moment, there was no personnel continuity from the interwar period into the new town leadership. None of the three members of the HSL'S elected in 1932 remained in the town leadership in these new circumstances. More radical members of the HSL'S succeeded, members who were not long-term directly elected actors of local politics in the town hall but who were in the main active only under the influence of events in the breakthrough period through the Slovak National Committee - in a parallel "revolutionary" body. They remained active in public life after 14 March 14 1939, which means that they fully adopted and represented the policies of the HSL'S leadership, the idea of independence and the ideological assumptions of the party formulated after 1939, but, as will be shown below, they did not generally become a permanent part of the town leadership.

\subsubsection{Nitra}

The municipal government in the town of Nitra was in a different situation in the autumn of 1938. Municipal elections had taken place in September 1931 and were again held in spring 1938, unlike in Prešov. Both took place under democratic conditions, although in 1938 they were already marked by increasing tensions.

In 1931, the HSL'S received five seats in the municipal assembly, thus joining the spectrum of stronger parties. This included the Land Christian Socialist Party (eight mandates), the Social Democrats (eight mandates), the Communists (seven mandates) and the National Socialists (four mandates). ${ }^{35}$ The HSL'S fought for a dominant position in the town with members of the Hungarian minority and with the Social Democrats. The Jewish minority also had a relatively strong position in the town leadership. However, this position was fragmented, members of the minority being active in several political parties. A total of 12 political parties were represented in Nitra's municipal assembly in 1931, among which, similarly to in the comparatively large Prešov, 42 mandates were divided.

The HSL'S was represented in the municipal assembly by František Mojto (formerly a teacher and at that time and until 1935 a member of the Chamber of Deputies of the National Assembly), Peter Rovnianek (head of the station, at that time elected deputy of the Slovak Land Assembly), Jozef Bednárik (retired teacher, died in October 1932), Imrich Rečka (landowner) and Dr Ladislav Nýbl (lawyer). ${ }^{36}$ Mojto and Rovnianek were also members of the municipal council. ${ }^{37}$

The five mandates did not entail any extraordinary position for the HSL'S in the municipal assembly. Mojto did not succeed in the election of the deputy mayor. The situation changed in the spring of 1932, when the mayor of the town, Dr Vojtech Szilágyi

34 In Prešov throughout the period under review, before 6 October 1938, in the time of autonomy, but also after 14 March 1939, the function of chief municipal notary was held by Rudolf Lieskovský, who represented a certain element of continuity. At the same time, it can be concluded that the regime considered him politically loyal.

35 ŠA Nitra, Pamätná kniha mesta Nitry II, fol. 35.

36 ŠA Nitra, Pamätná kniha mesta Nitry II, fol. 36.

37 ŠA Nitra, Pamätná kniha mesta Nitry II, fol. 41. 
(a Jewish lawyer and candidate for the Social Democrats), died. František Mojto was elected as the new mayor, and was to stay at the head of the town until $1945 .{ }^{38}$ The election of a member of the Czechoslovak parliament with contacts in the HSL'S party leadership as mayor created the preconditions for the strengthening of the positions of the HSL'S in the town's leadership.

In the municipal elections of 1938, the HSL'S won twice as many votes as in 1931 , which meant nine mandates in the municipal assembly. ${ }^{39}$ The Social Democrats with nine mandates and the coalition of the Hungarian and German minority parties, which received up to 11 mandates, remained the biggest competitors for the HSLS. Unlike in the previous municipal elections in the town, a candidate was also put up by the Slovak National Party (no mandate). F. Mojto was elected mayor with luck in August 1938. In a stalemate, with the same number of votes, the choice between him and the candidate of the Hungarian-German coalition was decided by lot. 40

Nitra entered the autumn crisis of 1938 with the newly elected town leaders. Its composition emerged from democratic elections and reflected not only the societywide development trends of the 1930s, such as the retreat of regional and local political parties or ethnic mobilization, but also a local specificity in the form of the symbolic importance of Nitra for Slovak society, which partly explains the gradual shift of voters to nationally oriented politics.

A direct participant in the autonomy declaration in Žilina, the HSL'S district secretary Vojtech Višňovský, spoke about the declaration of autonomy at a public meeting on 7 October 1938. A few days later, on 10 October, the Slovak National Committee was established in Nitra. To the leadership was elected the chairman of the local party organization Dr Jozef Buday (a canonist of Nitra, at that time the vice-chairman of the Senate of the National Assembly and one of the most famous politicians of the party active in national politics since the establishment of the Czechoslovak republic in 1918). The vice-chairmen became F. Mojto, P. Rovnianek and the lawyer Dr Stefan Klučovský. Overall, the committee finally had more than 30 members. The Slovak National Committee was involved in organizing public manifestations, which were frequently attended by young people and which took on an anti-Czech character. It also played an active role in organizing aid for refugees coming to the town as a result of the First Vienna Award. ${ }^{41}$

Looking at the situation in the town of Nitra in the "revolutionary" autumn of 1938, it can be stated that the seizure of power by the HSL'S was not associated with any rapid dramatic organizational changes in self-government. The HSL'S regime did not proceed to the immediate dissolution of the newly elected municipal assembly at that time and was satisfied that the HSL'S had a stable position in it. The significant strengthening occurred only after a delay in January 1939, when next 14 members were co-opted by the local party organization to the municipal assembly instead of left-wing and Jewish deputies, thus completing the personnel replacements. ${ }^{42}$ The local Slovak National Committee in Nitra was also created a few days later after the

38 ŠA Nitra, Pamätná kniha mesta Nitry II, fol. 50.

39 F. Mojto, P. Rovnianek, I. Rečka, V. Višňovský, Imrich Chovan (builder), Ján Tomasta (worker), Dr Karol Ďurček (teacher), Ján Dinka (railwayman), Jozef Bobek.

40 ŠA Nitra, Pamätná kniha mesta Nitry II, fol 88-89. See also: Slovák, 3 August 1938.

41 IZÁK-HVIEZDIN, Črty z pohnutých časov, 11. See also: Slovenský hlas, 15 October 1938.

42 ŠA Nitra, Pamätná kniha mesta Nitry II, fol. 91. 
declaration of autonomy. Considering the vice-chairmen, it is clear that this committee did not represent a fundamental power alternative to the elected town leadership. The stronger position of the HSLS and the personnel and political links between the Slovak National Committee and the town leadership, but also the leadership of the town with the Hlinka Guard, were largely the result of the circumstances surrounding the First Vienna Award, which directly threatened the town and its inhabitants. The feeling of being threatened had a linking effect. In this context, more significant interventions of the regime into the self-government of Nitra, more or less controlled by the HSL'S, would have had a counterproductive effect.

\subsection{Consolidation after 14 March 1939}

\subsubsection{Prešov}

In the following period, after 14 March 1939, and after some stabilization of the HSL'S regime, another phase of personnel replacements took place in the town leadership. From 1 May 1939, the Office of the Government Commissioner of the town was taken over by the politically agile representative of the HSL'S regime Andrej Germuška, who was meanwhile, a member of the autonomous Slovak parliament elected in December 1938 and continuously working as a body of the independent Slovak State after 14 March 1939. He appointed Jozef Kováč (police counsellor), Jozef Makara (teacher, primary school director), Július Róvó (bank director), Jozef Hlavatý (director of NUPOD - Purchasing Office of Agricultural Cooperatives), Vincent Šoltys (farmer) and Alexander Duchon (notary) as members of his advisory committee. ${ }^{43}$ We can state the following features in this new advisory committee:

1. The returns from the interwar period:

a. The return of long-term local politicians from outside the HSLS to the town leadership. These were the last two mayors of the town - Alexander Duchon (formerly Czechoslovak National Democracy) and Július Róvó (formerly Land Christian Socialist Party).

b. The return of an HSL'S long-term elected municipal deputy from the interwar period and at the same time a member of the "revolutionary" Slovak National Committee - Vincent Šoltys, who had had no place in the first appointed town leadership of October 1938.44

2. The arrival of persons coming from outside the HSL'S party structure or outside politics - from the economic sphere (Jozef Hlavatý - director of NUPOD) and from the state apparatus (Jozef Kováč - police counsellor, who, however, joined the Slovak National Committee in October 1938).

The new town leadership was appointed after the declaration of independence and after a short period of stabilization. The process of power consolidation was progressing, but the character of the town leadership had changed. Although in the narrow seven-member leadership were four former members of the "revolutionary" Slovak National Committee, at least three of them were certainly not members of the HSLS. Up to five out of the seven members of the new town leadership belonged to

\footnotetext{
43 Pamätná kniha mesta Prešova, 119-120.

44 There can be included the arrival of long-term chairman of the local party organization in Prešov and former deputy mayor Vojtech Raslavský to the position of government commissioner of the town in December 1940 (at a later stage of the period under review, see below), who, though little active, was swept away by the "revolutionary" events of autumn 1938. Overall, two of the three members of the HSL'S from the interwar period returned, although not simultaneously.
} 
the interwar municipal political elite, and their political past was not linked to the HSL'S. Two new people had come into the town leadership from outside politics, but were apparently loyal to the regime. This situation indicates a relatively significant degree of continuity with the interwar period in combination with that limited political pluralism which is a typological feature of the authoritarian regime. It also suggests a possible shortage of acceptable candidates in the HSL'S, a pool which was close to exhaustion with the co-opting of personnel from the external environment to meet the needs of the regime and the population's expectations. This heterogeneity in the town leadership had a significant impact on the practical performance of policy. It strengthened the position of the government commissioner. He could question the political reliability of his advisory committee in case of need, and, at the same time, situationally use inconsistencies on a situational basis to gain the support of this or that opinion group to legitimize his own political decisions towards the public.

Shortly after the Salzburg negotiations, on 31 August 1940, A. Germuška resigned from the post of government commissioner of the town. The door to higher politics had become open to him when, in addition to gaining his parliamentary mandate in January 1941 , he became deputy secretary general of the HSL'S. After the transitional period of office of Š. Malinovský the post of government commissioner of the town was occupied by member of the HSL'S, notary V. Raslavský at the end of $1940 .{ }^{45}$ A completely new advisory committee was also appointed. Unlike the previous ones, officially created by the government commissioners themselves, the advisory committee of December 1940 was based on a proposal of the Prešov local party organization. Apart from two exceptions (J. Makara and T. Ripka), there were new names, among them pioneers of the Prešov Hlinka Guard ${ }^{46}$ ]. Pavlík and A. Sabol-Palko (later the government commissioner of Prešov) and well-known construction businessman of Prešov and member of the German minority J. Patzelt, who were politically more radical. The members of the advisory committee were, for example, a priest, a worker, a teacher, a farmer, a baker, a businessman and a bank official. It can be stated that only as a result of the external intervention in the situation in Slovakia by Nazi Germany was the municipal political elite in Prešov replaced, the continuity of previous development completely disrupted and, at the same time, the character of the HSL'S regime changed. The leadership of the town was taken over by an experienced local party official, V. Raslavský, who was a member of the opposition before 1938 in an elected municipal assembly. The members of his advisory committee were all HSL'S nominees with predominantly more radical political positions (for example several members of the former "revolutionary" Slovak National Committee, active members of the Hlinka Guard and members of the German minority), which corresponded to the overall situation in the HSL'S after the Salzburg negotiations. Despite the fact that the number of advisory committee members increased compared to in the previous period, its activities were even more effective from the point of view of the regime. The advisory committee was largely disciplined along the party line, so outwardly more homogeneous. In term of practical

45 V. Raslavský resigned as the government commissioner in September 1942 after disagreements with the minister of the interior Alexander Mach. He was replaced by Anton Sabol-Palko who was supported by the minister and German consul Peter von Woinovich with his office in Prešov. ŠA PO, Notársky úrad Prešov 19301945 , no. 400/1942.

46 Hlinka Guard - paramilitary organization of the HSL'S, which was mainly associated with more radical members. 
politics, this leadership contributed to an increasing of the share of totalitarian elements in the non-democratic authoritarian regime of the Slovak State.

\subsubsection{Nitra}

The declaration of independence on 14 March 1939 did not bring a fundamental change in the municipal government of Nitra. Since the municipal elections of 1938, the HSL'S had dominated the municipal assembly. Their position was strengthened significantly after the replacement of left-wing and Jewish municipal deputies by HSL'S nominees in early 1939 . The town was still headed by F. Mojto. It seems that there were no major conflicts at the municipal level even among the members of the HSL'S, although there were changes at the local level in the party. There were no interventions from the regime in the self-government of the town and its personnel composition in 1939.

The dissolution of the originally elected, later co-opted municipal assembly took place in Nitra only on 4 November 1940. The municipal assembly was dissolved by the county governor Štefan Haššík, who came to Nitra shortly before 13 October, coincidentally from Prešov. F. Mojto was subsequently appointed as the government commissioner of the town. Dr Jozef Závodný (director of the hospital) was appointed as deputy. The advisory committee of the government commissioner consisted of: $\mathrm{Dr}$ Ján Rybárik (president of the regional court and also the chairman of the local party organization in Nitra), Michal Boleček (parson and organizer of Nitra's Hlinka Guard in 1938), Anton Válik (director of Tatra Banka), Štefan Jankela (tinsmith), Ján Kaňuch (vine-dresser), Vincent Boháč (worker), Viliam Gregory (retired military officer, for the German minority) and Dr Ákos Gyúrky (for the Hungarian minority). ${ }^{47}$ Until the adoption of the new legislation in 1943, this town leadership changed only minimally. J. Závodný resigned as deputy of the government commissioner in March 1941 and M. Boleček was appointed in his place. In 1943 Boleček was replaced by Vincent Hreusík (retired railwayman). In 1942, the advisory committee was expanded to include one more member, Štefan Letko (bishop's official and district leader of the Hlinka Youth ${ }^{48}$ ). ${ }^{49}$

It can be stated that shortly after external intervention by Nazi Germany in the summer of 1940 the municipal political elite in Nitra was replaced too, and the continuity through previous developments was disrupted. There was very limited personal continuity between the dissolved elected municipal assembly and the newly established appointed advisory committee. Apart from F. Mojto, from the 1930 s only Á. Gyúrky, who was a candidate of the Land Christian Socialist Party and was elected as a deputy in the municipal elections of 1931 and 1938, was to continue as part of the town leadership. ${ }^{50}$ Only Mojto, as a newly appointed government commissioner, and Gyúrky, appointed - to represent the Hungarian minority - as a member of the advisory committee, would represent continuity. The discontinuity also applies to former members of the municipal assembly elected for the HSL'S in 1938. None of them were to become members of the appointed advisory committee in November 1940 . Among the members of the advisory committee, there would be three people from

47 ŠA Nitra, Pamätná kniha mesta Nitry II, fol. 97.

48 Hlinka Youth - youth organisation subordinated to the HSL'S.

49 ŠA Nitra, Pamätná kniha mesta Nitry II, fol. 105.

50 In 1938, J. Kaňuch was a candidate for the HSL'S, but he was not elected. 
the dissolved municipal assembly, but these were people who had been co-opted by the HSL'S in January 1939, not duly elected in the 1938 elections. ${ }^{51}$

\section{Conclusion}

The replacement of municipal political elites associated with the deepening of the authoritarian character of the regime after the seizure of power by Hlinka's Slovak People's Party at the state-wide level was a gradual process that began in autumn 1938, but the most significant and final changes did not take place until the end of 1940 . This process cannot be understood only on the basis of the analysis of legislation. In practice this process was accompanied by a number of typical features, such as a continuity of the old elite in various forms in combination with the infiltration or co-optation also of new members from outside politics, but also with breaks caused by certain social groups being denied the possibility of joining the elite (students, power interventions of Germany).

The starting points of the analysis were the municipal elections held in interwar Czechoslovakia in 1931-1932 and 1938. After the elections, but also in the following months, the creation of the town leaderships was carried out according to a certain act, but socio-political circumstances and personnel relations in the leadership qualitatively deteriorated in connection with the international and internal political crisis caused by Nazi Germany in the autumn of 1938.

In the leadership of Prešov, the elected bodies were immediately, through power interventions from the centre and public demonstrations, replaced by appointed authorities. Not only the method of selection, but also the number of people in the town leadership was changed, which was reduced by $80 \%$. Thus, there was a seizure of power and at the same time its concentration in the hands of a narrow, more or less closed, group of persons of similar political beliefs and social status. There was also a change in the way in which power was exercised, because de jure the town was led by one government commissioner and the other members of the town leadership had only an advisory function, without real competences. Apart from the different positions and roles of these two bodies, the new HSL'S leadership of the town was homogeneous in terms of political, social, national and confessional composition. It contrasted with the character of the elected assembly, which reflected not only the political and social, but also the national (Slovak, Hungarian, Jewish etc.) and confessional (Roman Catholic, Greek Catholic, ${ }^{52}$ Protestant, Jewish etc.) composition of pre-war Prešov. Although the situation looked dramatic, the changes were not as fundamental and long-term as they might appear. The situation in Prešov changed even during the next months after the seizure of power by the HSL'S, because party members inwardly represented a very heterogeneous group with individual intentions. They were trying to occupy positions in the municipal government, which is to say they were attempting to gain political power. The dynamics of changes at the level of the municipal elite was also marked by the effort of the HSL'S members to change their own social statuses vertically.

Nitra represents another case. Shortly before the Munich crisis in 1938, a new town leadership was democratically elected. Although the HSL'S did not dominate in it, it gained a decisive influence in the overall strongly Catholic-oriented assembly through

51 For a full list of deputies, see, for example: ŠA Nitra, Mestský úrad v Nitre 1918-1948, Minutes of the Municipal Assembly, 10 March 1939, box 35.

52 The Slovak Greek Catholic Church is an Eastern Catholic church following the Byzantine rite. 
gradual steps connected with the removal of part of their political opponents. In a crisis intensified by the outcome of the First Vienna Award, which affected the town more than in the case of Prešov, it was not important for the regime to dissolve the politically and personally loyal town leadership. The members of the HSL'S in Nitra did not even face serious internal conflicts; therefore the HSL'S in the town leadership represented an element of continuity. The fraction of deputies of other political parties elected in the municipal elections of 1938 cooperated with the HSLS.

In both cases, significant personalities of the HSL'S linked to these two towns played an important role at the time of the autumn political crisis associated with the seizure of power. In Prešov it was Gejza Fritz, who had been active in high positions of the party since 1925 and who was involved at the local level in the breakthrough period of 1938. He held high state positions until autumn 1944. In Nitra it was Jozef Buday, who was one of the grey eminences of the HSL'S from the establishment of Czechoslovakia until his death in November 1939, and František Mojto, who had been deputy of the National Assembly for the HSL'S (1929-1935) and became a member of the constitutional body the State Council - in 1943. All three of them contributed to the seizure of power by the HSLS at the local level with their experience and authority.

In discussions on the evolution of the HSL'S regime, there is a consensus that historians see its roots in the period of autonomy between 6 October 1938 and 14 March 1939, when not only the foundations of the regime itself but also its parameters were laid. The regime was subsequently developed without any major changes. The change associated with the declaration of independence of the Slovak State brought some stabilization of the situation. While in Nitra the declaration of independence did not bring a change in the town leadership, in Prešov, where the HSL'S was inconsistent, the government commissioner and all but one of the members of the advisory committee were changed. Half the seats in the advisory committee were received by loyal people from outside the HSL'S at the expense of HSL'S members active in the fall of 1938.

A fundamental change in the regime of the Slovak State took place after July 1940 in connection with the Salzburg negotiations between the highest representatives of Nazi Germany and the Slovak State. Following the direct intervention of Germany, a radical pro-German wing in the HSL'S was strengthened, which resulted in personnel replacements directly in the government and in the structures of the HSL'S. At the same time, a prerequisite for potential personnel changes at lower policy levels was created. The interventions of Nazi Germany, whether at the highest level in the form of the Salzburg negotiations in the summer of 1940 or in the case of Prešov also in the form of the interventions of the German consul Peter von Woinovich, significantly contributed to radicalization and increasing elements of totalitarianism in the regime of the Slovak State. It was these interventions that caused discontinuities in the process of the replacement of municipal political elites in Prešov and Nitra. In Prešov, the town leadership was changed completely, with a strong representation of radical politics, including a representative of the German minority. In Nitra, the municipal assembly was dissolved at the end of 1940, and the government commissioner of the town and his advisory committee, with representatives of the German and Hungarian minorities, were appointed.

At the end of 1940, both towns came to the same result by different routes - elected municipal government was replaced by appointed authorities, who accumulated decisive power in the hands of one official (the government commissioner) and its advisory committee. In both analysed cases, the personnel composition of these bodies 
gave the impression of an effort to align the composition of the town leadership with the idea of corporate statism which was codified in the Constitution Act (No. 185/1939) on the one hand, but on the other hand did not correspond to the ideology of Nazism to which the radical wing of the HSL'S leaned after the Salzburg negotiations. The German minority was represented in the leadership of both towns.

Our comparative analysis showed that the historical development in Slovakia in the years 1938-1940 and the subsequently-continuing process of the replacement of municipal elites correlates with the framework that we formulated mainly on the basis of the sociological theories of V. Pareto (circulation) and R. Michels (intermixture). The power interference into the municipal elites went hand in hand with the degradation of self-government, the establishment or reinforcement of an authoritarian regime and the transfer of its ideological and programme pillars to practical politics. We also showed that in the process of the replacement of municipal elites, the characteristic elements of the authoritarian regime in the sense of the definition of J. J. Linz were strengthened, especially the influence of the (state and party) centre and citizen mobilization (especially in 1938). We confirmed the importance of the Salzburg negotiations of July 1940 as a milestone in the development of the regime in Slovakia in the years 1938-1945. It should not be forgotten that these developments in Slovakia were part of the process of the total seizure of power ("Machtergreifung") by the HSL'S, which was inspired by analogous processes in fascist Italy and Nazi Germany and aimed at the establishing of totalitarianism with fascist elements.

\section{BIBLIOGRAPHY}

Štátny archív v Prešove [State Archives in Prešov], Okresný úrad Prešov 1923-1945 [District Office in Prešov 1923-1945]

Štátny archív v Prešove [State Archives in Prešov], Notársky úrad Prešov 1930-1945 [Notary Office in Prešov 1930-1945]

Štátny archív v Prešove, [State Archives in Prešov], Šarišsko-zemplínska župa 1940-1946 [Šariš-Zemplín County 1940-1946]

Štátny archív v Nitre [State Archives in Nitra], Nitrianska župa III [Nitra County III]

Štátny archív v Nitre [State Archives in Nitra], Mestský úrad v Nitre 1918-1948 [District Office in Nitra 1918-1948]

Štátny archív v Nitre [State Archives in Nitra], Pamätná kniha mesta Nitry II

IZÁK-HVIEZDIN, Ján. Črty z pohnutých časov v Nitre 1938-1939. Nitra: Prvá slovenská tlačiareň, 1940.

Pamätná kniha mesta Prešova. Diel III. (1938-1941). Prešov: Štátna vedecká knižnica v Prešove, 2011.

Smernice pre navrhovanie členov a náhradníkov obecného výboru. Bratislava: Slovenská ludová kníhtlačiareň, [b. r.].

Sbírka zákonů a nař́zení Republiky československé 1919, 1922.

Nitrianska stráž 1939-1940.

Slovák 1938-1940.

Slovenská sloboda 1939-1940.

Slovenský hlas 1938.

Slovenský zákonník 1939, 1942, 1943.

BAKA, Igor. Politický systém a režim Slovenskej republiky 1939-1940. Bratislava: Vojenský historický ústav, 2010. 
BYSTRICKÝ, Valerián. Slovakia from the Munich Conference to the declaration of independence. In: TEICH, Mikuláš - KOVÁČ, Dušan - BROWN, Martin D. (eds.). Slovakia in History. New York: Cambridge University Press, 2011, pp. 157-174.

BYSTRICKÝ, Valerián. Politické rozvrstvenie spoločnosti na Slovensku vo svetle obecných volieb roku 1938. In: BYSTRICKÝ, Valerián. Od autonómie k vzniku Slovenského štátu. Výber zo štúdií. Bratislava: HÚ SAV, 2008, pp. 120-137.

FERENČUHOVÁ, Bohumila - ZEMKO, Milan et al. V medzivojnovom Československu 19181939. Bratislava: Veda, 2012.

FUSEK, Gabriel - ZEMENE, Marián Róbert. (eds.). Dejiny Nitry: Od najstarších čias po súčasnost. Nitra: Mesto Nitra, 1998.

HOENSCH, Jörg K. Die Slowakei und Hitlers Ostpolitik: Hlinkas Slowakische Volkspartei zwischen Autonomie und Separation 1938-1939. Köln; Graz: Böhlau Verlag, 1965.

HRADSKÁ, Katarína - KAMENEC, Ivan et al. Slovenská republika 1939-1945. Bratislava: Veda, 2015.

KAMENEC, Ivan. Politický systém a režim slovenského štátu v rokoch 1939-1945. In: KAMENEC, Ivan. Hladanie a blúdenie v dejinách. Bratislava: Kalligram, 2000, pp. 63-81.

KELLER, Jan. Dějiny klasické sociológie. Praha: Slon, 2004.

LINZ, Juan J. An Authoritarian Regime: The Case of Spain. In: ALLARDT, Erik LITTUNEN, Yrjö (eds.). Cleavages, Ideologies and Party Systems: Contribution to Comparative Political Sociology. Helsinki: Westermarck Society, 1964, pp. 291-341.

LINZ, Juan J. Totalitarian and Authoritarian Regimes: With a Major New Introduction. Boulder; London: Lynne Rienner Publisher, 2000.

LIPTÁK, L’ubomír. Príprava a priebeh salzburských rokovaní roku 1940 medzi predstavitelmi Nemecka a Slovenského štátu. In: Historický časopis, 1965, vol. 13, no. 3, pp. 329-365.

LORMAN, Thomas. The Making of the Slovak People's Party: Religion, Nationalism and Culture War in Early 20th-Century Europe. London: Bloomsbury Academic, 2019.

LUPTÁK, Ludovít. Šariš v budovaní slovenskej štátnosti. Bratislava: Slovenská ludová tlačiareň, 1939.

MICHELS, Robert. Political Parties: A Sociological Study of the Oligarchical Tendencies of Modern Democracy. New York: Hearst's International Library Co., 1915.

MOSCA, Gaetano. The Ruling Class. New York; London: McGraw-Hill Book Company, 1939.

NIŽŇANSKÝ, Eduard. Zmocnenie sa vlády HSL'S v roku 1938/39 na Slovensku a „Machtergreifung“ 1933/34 v Nemecku. In: NIŽŇANSKÝ, Eduard. Nacizmus, holokaust, slovenský štát. Bratislava: Kalligram, 2010, pp. 14-44.

PALÁRIK, Miroslav - MIKULÁŠOVÁ, Alena - HETÉNYI, Martin - ARPÁŠ, Róbert. The City and Region against the Backdrop of Totalitarianism. Berlin: Peter Lang, 2018.

PARETO, Vilfredo. The Circulation of Elites. In: Theories of Society: Foundations of Modern Sociological Theory. Volume I. New York: The Free Press of Glencoe, 1961, pp. 551-558.

PEKÁR, Martin. Dr. Gejza Fritz - zabudnutý príbeh ludáckeho poslanca a ministra. In: MAREK, Pavel et al. Jan Šrámek a jeho doba. Brno: Centrum pro studium demokracie a kultury, 2011, pp. 394-404.

PEKÁR, Martin. Prešov 1938-1945: Kapitoly z dejín mesta a jeho obyvatelov. In: Pamätná kniha mesta Prešova. Diel III. (1938-1941). Prešov: Štátna vedecká knižnica v Prešove, 2011, pp. XVII-LIV.

PEKÁR, Martin. Štátna ideológia a jej vplyv na charakter režimu. In: Slovenský štát 1939_ 1945: predstavy a realita. Bratislava: Historický ústav SAV, 2014, pp. 137-152.

PEKÁR, Martin - TOKÁROVÁ, Zuzana. Výmeny mestských politických elít na Slovensku po páde medzivojnovej československej demokracie (Prešov, 1938-1944). In: Studia historica Nitriensia, 2019, vol. 23, no. 1, pp. 144-157.

PEKÁR, Martin. Zlomové udalosti 20. storočia v syntézach dejín vybraných slovenských miest. Poznámky k trendom vo výskume. In: Jak psát dějiny vekých měst? Brno: Město Brno; Archív města Brna, 2016, pp. 120-131. 
PEKÁR, Martin. Zmeny v samospráve a volby do obecných výborov v roku 1944 so zretelom na východ Slovenska. In: Dejiny, 2008, vol. 3, no. 1, pp. 83-90. http://dejiny.unipo.sk/PDF/ Dejiny_1_2008.pdf.

PODOLEC, Ondrej. Postavenie obecnej samosprávy na Slovensku v rokoch 1938-1945. In: Historický časopis, 2003, vol. 51, no. 4, pp. 647-668.

PODOLEC, Ondrej. Volení i menovaní... Kreovanie správnych orgánov obcí na Slovensku v rokoch 1918-1945. In: FASORA, Lukáš - HANUŠ, Jiří - MALÍŘ, Jiří (eds.). Občanské elity a obecní samospráva 1848-1948. Brno: CDK, 2006, pp. 165-173.

PUTNAM, Robert D. The Comparative Study of Political Elites. Englewood Cliffs, N. J.: Prentice-Hall. 1976.

ŘÍCHOVÁ, Blanka et al. Analýza politiky a političtí aktéři: Možnosti a limity aplikace teorií $v$ př́kladech. Praha: Slon, 2015.

SZEGHY-GAYER, Veronika. „Vrátme si mesto!“ Prejavy nespokojnosti „mestského občana” v politickom diskurze v Prešove 1918-1938. In: Forum Historiae, 2015, vol. 9, no. 2, pp. 56-68.

TOKÁROVÁ, Zuzana. Legislative Interventions into the Creation of Local Political Elites as an Instrument of Anti-Jewish Policy during the Holocaust (A Comparative View). In: Mesto a dejiny, 2019, vol. 8, no. 1, pp. 80-109.

TOKÁROVÁ, Zuzana. Slovenský štát: Režim medzi teóriou a politickou praxou. Košice: Univerzita Pavla Jozefa Šafárika v Košiciach, 2016.

TÖNSMEYER, Tatjana. Kollaboration als handlungsleitendes Motiv? Die slowakische Elite und das NS-Regime. In: Kooperation und Verbrechen: Formen der Kollaboration in Südostund Osteuropa 1939-1954. Göttingen: Wallstein, 2003, pp. 25-54.

WARD, James Mace. Priest, Politician, Collaborator: Jozef Tiso and the Making of Fascist Slovakia. Ithaca; London: Cornell University Press, 2013.

WASNER, Barbara. Eliten in Europa: Einführung in Theorien, Konzepte und Befunde. Wiesbaden: Springer Fachmedien, 2006.

WEBER, Max. Wirtschaft und Gesellschaft. Tübingen: Mohr, 1922.

ZUBÁCKA, Ida. Vývoj a činnost' mestskej správy v Nitre v rokoch 1918-1938. In: Nitra v slovenských dejinách. Martin: Matica slovenská, 2002, pp. 369-383. 


\section{Appendix A}

Overview - the HSL'S in the town leadership of Prešov in the years 1938-1940

\begin{tabular}{|c|c|c|c|c|}
\hline $\begin{array}{c}\text { (1932) to } 1938- \\
10-27\end{array}$ & $\begin{array}{c}1938-10-27 \text { to } \\
1939-05-01\end{array}$ & $\begin{array}{c}1939-05-01 \text { to } \\
1940-08-31\end{array}$ & $\begin{array}{c}1940-08-31 \text { to } \\
1940-12-13\end{array}$ & $\begin{array}{c}\text { After } \\
1940-12-13\end{array}$ \\
\hline $\begin{array}{l}\text { Mayor, elected, } \\
\text { A. Duchoň }\end{array}$ & $\begin{array}{c}\text { Government } \\
\text { commissioner, } \\
\text { appointed, } \\
\text { A. Chrappa }\end{array}$ & $\begin{array}{l}\text { Government } \\
\text { commissioner, } \\
\text { appointed, } \\
\text { A. Gemuška }\end{array}$ & $\begin{array}{l}\text { Government } \\
\text { commissioner, } \\
\text { appointed, } \\
\text { Š. Malinovský }\end{array}$ & $\begin{array}{c}\text { Government } \\
\text { commissioner, } \\
\text { appointed, } \\
\text { V. Raslavský (from } \\
\text { September 1942 } \\
\text { A. Sabol-Palko) }\end{array}$ \\
\hline $\begin{array}{c}\text { Municipal council } \\
\text { (15 members }{ }^{53}+ \\
\text { notary ex offo); } \\
\text { Members for } \\
\text { the HSL'S or } \\
\text { connected later } \\
\text { with the HSL'S: } \\
\text { J. Makara } \\
\text { J. Róvó } \\
\text { A. Duchoň } \\
\text { V. Raslavský }\end{array}$ & $\begin{array}{c}\text { Advisory } \\
\text { committee } \\
\text { (8 members), } \\
\text { appointed: } \\
\\
\text { J. Makara } \\
\text { T. Ripka } \\
\text { A. Germuška } \\
\text { F. Staš } \\
\text { J. Meličko } \\
\text { A. Válik } \\
\text { J. Onofrej } \\
\text { F. Pjontek }\end{array}$ & $\begin{array}{c}\text { Advisory } \\
\text { committee } \\
\text { (6 members), } \\
\text { appointed: } \\
\\
\text { J. Makara } \\
\text { J. Róvó } \\
\text { A. Duchoň } \\
\text { J. Kováč } \\
\text { J. Hlavatý } \\
\text { V. Šoltys }\end{array}$ & $\begin{array}{c}\text { Advisory } \\
\text { committee } \\
\text { (6 members), } \\
\text { appointed: } \\
\\
\text { J. Makara } \\
\text { J. Róvó } \\
\text { A. Duchoň } \\
\text { J. Kováč } \\
\text { J. Hlavatý } \\
\text { V. Šoltys }\end{array}$ & $\begin{array}{c}\text { Advisory } \\
\text { committee } \\
\text { (10 members), } \\
\text { appointed: } \\
\text { J. Makara } \\
\text { T. Ripka } \\
\text { J. Bombík } \\
\text { Š. Gmitro } \\
\text { Š. Hések } \\
\text { A. Kobulský } \\
\text { J. Pavlík } \\
\text { J. Patzelt } \\
\text { A. Sabol-Palko } \\
\text { D. Sokolík }\end{array}$ \\
\hline $\begin{array}{c}\text { Municipal } \\
\text { assembly- } \\
42 \text { elected } \\
\text { members } \\
\text { Members elected } \\
\text { in } 1932 \text { for the } \\
\text { HSL'S: } \\
\text { V. Raslavský } \\
\text { V. Šoltys } \\
\text { Š. Haluška }\end{array}$ & & & & \\
\hline
\end{tabular}

53 Selected from deputies of the Municipal assembly. 


\section{Appendix B}

Overview - the HSL'S in the town leadership of Nitra in the years 1938-1940

\begin{tabular}{|c|c|c|c|}
\hline $\begin{array}{c}\text { Election of } \\
1931\end{array}$ & $\begin{array}{l}\text { Election of } \\
\text { May } 1938\end{array}$ & $\begin{array}{l}\text { Co-optation of } \\
\text { January } 1939\end{array}$ & $\begin{array}{l}\text { Appointment of } \\
\text { November } 1940\end{array}$ \\
\hline $\begin{array}{l}\text { Mayor, elected, } \\
\text { from 1932, F. Mojto } \\
\text { (for the HSL'S) }\end{array}$ & $\begin{array}{l}\text { Mayor, elected, } \\
\text { F. Mojto }\end{array}$ & $\begin{array}{l}\text { Mayor, elected, } \\
\text { F. Mojto }\end{array}$ & $\begin{array}{l}\text { Government } \\
\text { commissioner, } \\
\text { appointed, } \\
\text { F. Mojto } \\
\text { Deputy Government } \\
\text { Commissioner } \\
\text { J. Závodný }\end{array}$ \\
\hline $\begin{array}{l}\text { Municipal assembly - } \\
42 \text { elected members }\end{array}$ & $\begin{array}{l}\text { Municipal assembly - } \\
42 \text { elected members }\end{array}$ & $\begin{array}{l}\text { Municipal assembly - } \\
42 \text { elected (1931) and } \\
\text { co-opted members }\end{array}$ & $\begin{array}{l}\text { Advisory committee } \\
\text { (8 members), } \\
\text { appointed }\end{array}$ \\
\hline $\begin{array}{l}\text { Members elected in } \\
1931 \text { for the HSL'S: } \\
\text { F. Mojto } \\
\text { P. Rovnianek } \\
\text { I. Rečka } \\
\text { J. Bednárik } \\
\text { L. Nýbl }\end{array}$ & $\begin{array}{c}\text { Members elected in } \\
1938 \text { for the HSLS: } \\
\text { F. Mojto } \\
\text { P. Rovnianek } \\
\text { I. Rečka } \\
\text { V. Višňovský } \\
\text { I. Chovan } \\
\text { J. Tomasta } \\
\text { K. Durček } \\
\text { J. Dinka } \\
\text { J. Bobek }\end{array}$ & $\begin{array}{l}23 \text { members for the } \\
\text { HSL'S (9 elected, } 14 \\
\text { co-opted) } \\
\text { Among co-opted for } \\
\text { the HSL'S: } \\
\text { J. Závodný } \\
\text { Š. Jankela } \\
\text { J. Kaňuch }\end{array}$ & $\begin{array}{l}\text { J. Rybárik } \\
\text { M. Boleček } \\
\text { Š. Jankela } \\
\text { A. Válik } \\
\text { J. Kaňuch } \\
\text { V. Boháč } \\
\text { V. Gregory }\end{array}$ \\
\hline Á. Gyūrky & Á. Gyúrky & Á. Gyūrky & Á. Gyūrky \\
\hline
\end{tabular}

